\title{
63. 手術用無影灯の光学的性能評価
}

\section{1. 研究目的}

手術用無影灯は近年その種類む多く，使用者側としてもそ れぞれの特徵を充分理解し，その適纫を決める必要がある。

しかし，現状においてはそれらの相対的性能評価に関する 試験結果は皆無に等しい状態にある。そこで今回, 関連各位 の協力を得ながら研究会を組織し，臨床に供する各種無影灯 の総合的性能評価を行なったので, そのうちの光学的性能評 価の結果について報告する。

\section{2. 方 法}

検討に供した手術用無影灯は，7社の13種類であるが，今 回の報告では補助灯 3 種類ははぶき, 10 種類の主灯について のみ報告する。

検討を行なった項目は, 照度, 光野色温度, 無影度, 放射 照度である。

照度測定は, 図 1 のごとく, 灯面より $107 \mathrm{~cm}$ の距離におい て照度計（SPI-71, TOPCON, 測定範囲 $300 \mathrm{Klx}$ ）によっ て行なった。無影灯に照度調節装置が組み込まれている機種 においては最大の照度で測定した。

光野は, IESのlighting handbook(1981)に記載されてい るように, 中心照度の $20 \%$ 以上の照度範囲の直径として表現 した。

色温度は, 同じ距離に打いて色温度計 (XY-DC Minolta) によって測定したX，Yより色度図によって求めた。IESの 規格による無影灯は, 灯面より $107 \mathrm{~cm}$ 位置に照度計を設置 し, この上に直計 $50 \mathrm{~mm}$, 高さ $76 \mathrm{~mm}$ の黒色円筒を置き, 更に照 度計より $58 \mathrm{~cm}$, 灯面から $49 \mathrm{~cm}$ の中央に, 直径 $254 \mathrm{~mm}$ の黑色円 板を置いた際の最大照度に対する百分率であり, IESでは 10 \%以上の照度を要求している。また図一 2 の如き, クローバ 一型の黒色円板を遮光板とし， 4 人の術者団の頭に模した場 合の無影度も同様（距離同じ）にして求めた。

\section{3. 成 結}

$\mathrm{A} \sim \mathrm{D}$ の無影灯は国産品であり，E～I は輸入品であるが, $F_{1}, F_{2}$ は, 2 灯で 1 組であり，E，H，Iには補助灯が付いて いる。最大照度は, 表 1 の通りでいずれるIESの規格値, 27 Klx をはるかに越えている。この $20 \%$ を保つ範囲の直径, 光 野は, IES 規格では值径 $25.2 \mathrm{~cm}$, 面積 $500 \mathrm{~cm}^{2}$ であるが, Hを 徐いて他は $25 \mathrm{~cm}$ 以下の直径である。しかし，照度が十分高い ことから，いずれも問題はないものと考える。光野の面積で 最大照度を割った值は, 解釈がむずかしい面むあるが, 一応, 光野に扮ける光の強さを示すあの上考えられる。

色度座標, $\mathrm{X}, \mathrm{Y}$ 上り求めた色温度は, 表 2 のでよくで, 5,000 K以上のものはI のみで, $\mathrm{C}, \mathrm{F}_{1}, \mathrm{~F}_{2}, \mathrm{G}$ が 4,150〜 4,250 Kであり, Dが $4,000^{\circ} \mathrm{K}, \mathrm{A}, \mathrm{B}, \mathrm{H}$ が, $3,750^{\circ} \mathrm{K}, \mathrm{E}$ が最む低く、3,350Kであった。

IES の方法による無影度は, 表 3 の通りでいずれも満足す べき值を示しており， $F_{1}, F_{2}$ が多少低めであるが, これは 2 灯
東京大学中央手術部

小林宽伊都築正和
で 1 対となっている点を考虑する時, 十分な值と考える。 全放射照度, および $40,0001 \mathrm{x}$ の時の放射照度, $40 \mathrm{~K} 1 \mathrm{x}$ 放射 照度は, 表 4 のでとくである。

\section{4. 考 察}

色温度について, IESが満足す心゙き範囲として示す 5 角形 との位置関係を見たあのが図 3 であり，乙の 5 角形は 3,500 ${ }^{\circ} \mathrm{K}$ から $6,700^{\circ} \mathrm{K}$ の間にある。

また, 色温度が高くなるにつれて, 色は白色となって昼光 に近くなり，低くなると赤っぽい色となる。I を除いて他は すべて 5 角形の右上方にかたまっており，比較的赤っぽい色 を好む日本人外科系医師に合わせてあるかに思われる。

米国においてWillam Backが外科医を対称としておしなっ た調査結果では，図 4 のごよく，5,000KKピークがあり， 米国外科医の好みが, 日本の場合にくらべてかなり色温度の 高い方，つまり白っぽい色纪寄っているととがわかる。

IES の万法では, 光源の範囲が広いほよ゙, 無影度は高い值 となる。黒色円筒のみの影響を見たのが梁度であるが, 黒色 円板の影響つまり, IES 無影度と㳭度との差が大きいむのは $\mathrm{A}, \mathrm{D}, \mathrm{F}$ 等でありいずれも光源の範囲が决い灯であり， $\mathrm{G}$, Iのようにほとんど差がないものと対照的である。このよう なそれぞれの特徴を理解し，それを生かした使用方法が重要 である。クローバー型の遮光板を用いた無影度は，4人の術 者の頭を想定したものであるが，機種によって，かなりの差 が認められる。また, IES 無影度とほぼ同等なものとクロー バー型の方が大きい值を示す $\mathrm{A}, \mathrm{D}, \mathrm{F}$ など, クローバー型の 方が小さな值を示す I などがある。

全放射照度に関してIESでは，ある種つ脳神経外科および

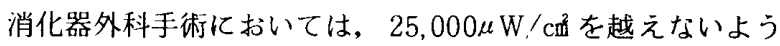
注意する必要があると述べられている。照度を40,0001x と した時の放射照度では，ほとんどが $25,000 \mu \mathrm{W} / \mathrm{cm}$ 以下とな る。照度 $1 \mathrm{~lx}$ 当りの放射照度は, 一定の明るさを得る為に生 ずる放射照度であり，ほとんどが同等な值を示している。

\section{5. 結 論}

以上, 種々の無影灯に関し, 光学的性能を比較評価したが, メーカーにより, それぞれが特徴を有しており, 各々の光学

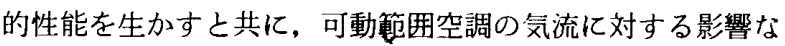
どをす考慮して目的に合った機種を選択するてとが朋要と考 える。

共通の試験方法で, 異なった性能を有する無影灯を比較す るととは, 多少の問題はあるが, 今回の検討結果が無影灯 評価の新しいステップとなるととを確信する。

（本研究にご協力いただいた研究会の各位に深謝する。） 

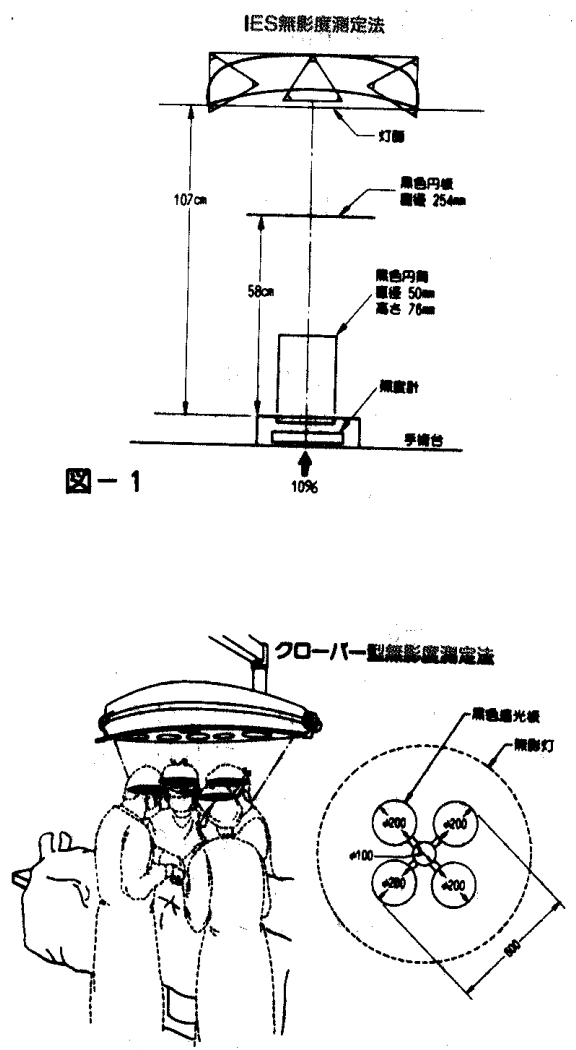

国-2

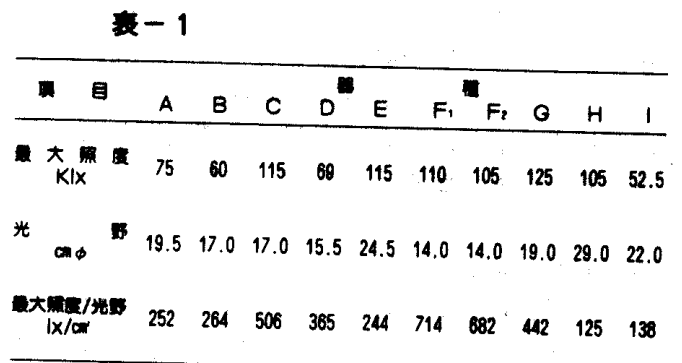

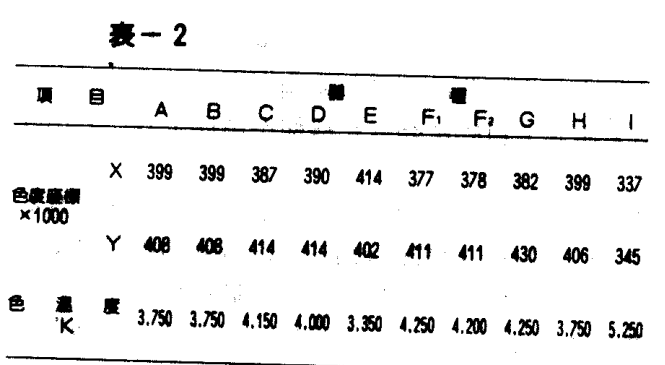
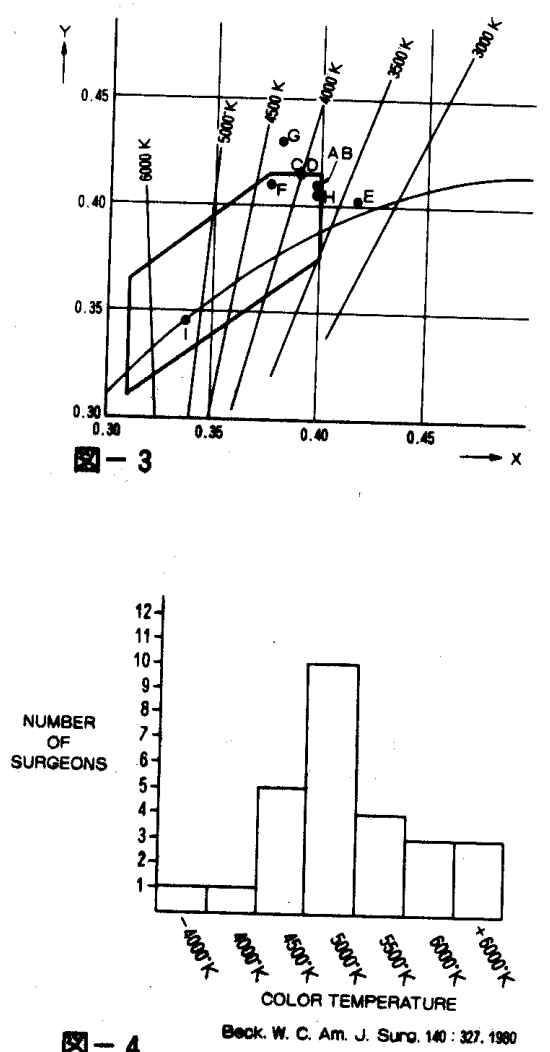

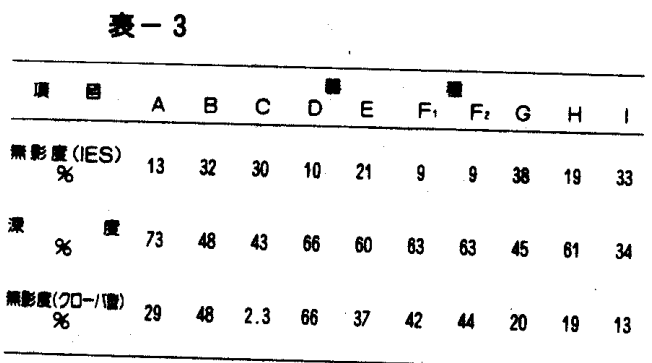

\begin{tabular}{|c|c|c|c|c|c|c|c|c|c|c|c|}
\hline W & 目 & A & $B$ & $C$ & $0^{\circ}$ & $E$ & $\mathrm{~F}$, & $\mathrm{F}_{2}$ & $G$ & $\mathrm{H}$ & 1 \\
\hline \multirow{2}{*}{ 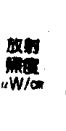 } & 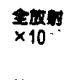 & 16.6 & 13.5 & 26.3 & 16.8 & 42.5 & 24.1 & 24.1 & 27.3 & 26.5 & 57.6 \\
\hline & $\begin{array}{l}40 \mathrm{~K} / \mathrm{x} \\
\times 10^{-1}\end{array}$ & 8.5 & 9.4 & 8.9 & 9.9 & 16.6 & 8.7 & 8.7 & 8.7 & 10.5 & 42.8 \\
\hline 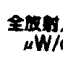 & $/ / 0+1 / 1 x$ & 0.22 & 0.22 & 0.23 & 0.24 & 0.37 & 0.22 & 0.23 & 0.22 & 0.25 & 1.10 \\
\hline
\end{tabular}


No. 63 付 議

\section{大阪大池田卓 也}

無影灯に使われる電球はほとんど規格されて いるが，色温度にバラエティがあるのは意識的 に設計したものか？また，色温度について先 生のご意見は。

回 答

\section{東宗大 小 林 寞 伊}

今回検討したランプのほとんどは, IESの示 す 5 角形の右上方に位置しており，日本人外科 系医師が比較的赤っぽい色を好む傾向にあるか とも考之られる.W. Beckの米国における調査 では， $5,000^{\circ} \mathrm{K} に$ 好みのピークがあり，日本と はやや異なっている。 